\author{
Humanities and Social Sciences Letters \\ 2022 Vol. 10, No. 1, pp. 1-10. \\ $\operatorname{ISSN}(e): 2312-4318$ \\ $\operatorname{ISSN}(p): 2312-5659$ \\ DOI: $10.18488 / 73 . v 10 i 1.2176$ \\ (C) 2022 Conscientia Beam. All Rights Reserved. \\ check for
updates
}

\title{
FERTILITY AND HOUSEHOLD WELFARE IN NIGERIA: A TIME SERIES ECONOMETRIC APPROACH
}

\author{
Ovikuomagbe \\ Oyedele
}

\author{
Department of Economics, Babcock University, Ogun State, Nigeria. \\ Email:oyedeleov@babcock.edu.ng Tel: +2348028436256
}

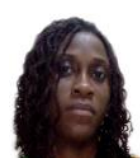

\section{Article History}

Received: 19 July 2021

Revised: 22 November 2021 Accepted: 14 December 2021 Published: 3 January 2022

\section{Keywords}

Total fertility rate Household welfare Household consumption Expenditure Real GDP per capita Nigeria.

\section{ABSTRACT}

This study examines the effect of fertility levels on household welfare in Nigeria during the period from 1980 to 2020. Using data from the World Development Indicators for 2021, the estimation process began with a unit root test for the stationarity of the variables. A bounds cointegration test showed the presence of a long-run relationship between household consumption expenditure and fertility, but the result was inconclusive when real GDP per capita was used as a welfare proxy. The ARDL model was employed and the results showed that fertility had a negative, significant effect on household consumption per capita only in the short run. The effect was from previous years thereby showing a lagged effect. However, when welfare is measured using real GDP per capita, there were both short-run and long-run effects, such that Kuznets' hypothesis of an inverted U-shaped relationship was obtained in the short run. In the long run, however, the relationship becomes U-shaped, implying that there is the possibility of a demographic dividend in the long run. Fertility policies must endeavor to control for the immediate or short-run negative effects of rising fertility rates and make deliberate plans to engage the future large working population in order to reap the possible demographic dividend.

Contribution/Originality: This study contributes to existing literature by examining the effect of fertility on household welfare in Nigeria using a macroeconometric approach, since most previous studies applied a microeconometric perspective. The primary contribution is investigating whether the Kuznet curve of an inverted U-shaped relationship applies to fertility and household welfare.

\section{INTRODUCTION}

The poor welfare levels of households in Nigeria cannot be overemphasized, as shown by the low level of household consumption expenditure presented in the World Bank (2021). There have been several declines in household consumption expenditure over the 38-year period of this study. Consistent declines were seen from 1997 to 2000,2010 to 2012 , and 2014 to 2017 . Other recorded declines include a $24.8 \%$ fall experienced in 1983 , and $15 \%$ and $18 \%$ declines in 2006 and 2008, respectively, which reveals that there has been no steady or consistent growth. Despite the large percentage growth of household consumption expenditure recorded to the tune of $55 \%, 32 \%$ and 19\% in 2001, 2007 and 2009, respectively, poverty among households is still a big challenge.

Even with the recorded declines in the total fertility rate over the years, Nigeria still remains one of the countries with a high fertility rate; in 2020 it stood at 5.3 based on the World Bank (2021). High fertility rate escalates the total population and this becomes a crisis when the total population is greater than the available resources. Are there implications of the high fertility rate on the standard of living and welfare levels of Nigerians? 
Studies exist that have examined the effect of fertility on welfare in both developed and developing countries. There are several studies that have used the microeconomic approach but only a few attempts have been made to examine the macroeconomic perspective of the effect of fertility on welfare, for instance, the macroeconomic study for Poland done by Makarski, Tyrowicz, and Malec (2019). Using the macroeconomic approach, we also examine if there is an inverted $\mathrm{U}$ relationship or turning point in the fertility effect on welfare.

\section{LITERATURE REVIEW}

Desta (2014) presented empirical evidence that high fertility levels reduce the well-being of households in Ethiopia. Thus, as the number of children increased thereby increasing the number of household members, consumption expenditure per capita declined. He found this to be significant for the rural sample but not among urban households.

Studies have shown that changes in the demographic structure of a country's population determine consumption levels. An increase in population would also increase total consumption. If the population structure of a country changes in terms of the percentage of the population that are children, young adults and the elderly, then the composition of consumption would also change depending on the different needs of the various age groups. Huang, Pan, Chang, and You (2019) argued that demographic transition not only affects the accumulation of human capital in an economy but also affects the population structure and, consequently, brings about a change in the consumption structure. Examining the effect of low fertility rate on consumption behavior of households in Taiwan, Huang et al. (2019) found that a low fertility rate changes the composition of goods and services consumed, such that while it increases the share of total consumption expenditure on food, education, healthcare, transportation and communication of a household's disposable income, it reduces the expenditure share on clothing. The immediate impact of increased fertility is a fall in labor supply and a decline in the consumption level of adults (Makarski et al., 2019).

Using Nigerian survey data, Caldwell (1977) explained that high fertility will be increasingly disadvantageous to society as more westernization is embraced, and not because of modernization. Kanayo, Chinelo, and Sathiya Susuman (2016) also found that differentials in fertility rate affect the demand portfolio of households in Nigeria. Masanja, Lwankomezi, and Emmanuel (2016) examined the effect of fertility decline on socioeconomic variables among women in Kwimba district, Tanzania. Fertility decline was measured by whether a woman had given birth to more than her desired number of children. They found that households with a higher number of children had lower consumption expenditure. They also found that higher income households had a lower dependency ratio.

Examining the effect of fertility on poverty, Libois and Somville (2018) showed that for mothers with completed fertility in Nepal, there was no significant correlation between the number of births and households' per capita consumption. However, for younger mothers, there was a reduction in consumption per capita as the number of births increased. High fertility has also been found to worsen household consumption expenditures, especially on food. In Nigeria, urban households with a higher number of children had lower per capita food expenditure (Owoo, 2021). This study, however, uses an aggregate household consumption expenditure that captures more than just food.

The effect of fertility changes on wealth was shown to have only a small magnitude by Wusu and Amoo (2016) using the 2013 Nigeria demographic and health survey. Thus, other factors including age at first marriage, use of modern contraception and marital status were significantly responsible for explaining changes in the wealth status of men and women.

Schultz (2005) analyzed the relationship between fertility and income in Kenya and used household consumption per adult as an indicator for income. The findings showed that an increase in fertility levels caused household consumption to decline. However, a fertility increase associated with the birth of twins was not 
significant enough to explain household consumption per adult. An increase in mothers' schooling also increased household consumption.

Investigating the effect of fertility on poverty, Kim, Engelhardt, Prskawetz, and Aassve (2005) found that the correlation between both variables was not decisive when welfare was measured by the share of food in the total expenditure. In Indonesia, when consumption expenditure per capita was used as a welfare measure, having an additional child did not necessarily depress household welfare when there were lower economics of scale and equivalence scales at the household level. The study argues that using the per capita household expenditure assigns an equal value to all household members, children and adults alike, and ignores the economics of scale associated with household size.

Some studies have also shown that welfare levels may explain the fertility rate in some countries. This portrays a two-way causality in the literature for the relationship between fertility and welfare. For instance, Moffitt (1998) explained that welfare programmes that ultimately reduce the cost of having an additional child encourage higher fertility among women. Brewer and Ratcliffe (2012) also found that there were increases in births among coupled women as a result of welfare reforms that increased the spending per child by $50 \%$ in real terms in the UK among low income households.

Some studies, including Becker (1960), have shown that fertility increases as income rises since parents are able to cater for more children as their income rises. This is also possible when parents prefer to have a larger number of children. However, Becker (1965) presented a negative effect of women's participation in the labor market on fertility. This is because if a woman wants to have more children, she would have to forgo earning a higher income. Schultz (2005) also found that income was a significant determinant of fertility and while sources of income such as household assets had a positive effect, a negative effect was seen when household income came from sources such as labor earnings as a result of the associated opportunity cost of having children.

Some studies, including Odusola (2018), have shown that poverty also determines the fertility preferences of households. Thus, poor households have begun to realize the need to reduce the number of children that they would have to cater for. Using primary data from Lagos and Kaduna and a focus group discussion, he found that poverty significantly explained the fertility decline in Nigeria.

Other studies have shown that there are several determinants of household welfare. Yusuf (2008) found social capital to positively affect household welfare. Households that are members and active participants of associations contribute to improving welfare levels. Using the NDHS 2013, women labor participation and female education were significant for improving household wealth (Obiyan, Fagbamigbe, Adetutu, \& Oyinlola, 2017). Fertility was positively significant in explaining household consumption, as shown by Adebiyi and Olomola (2016). Female education was also positively significant; however, female employment reduced household consumption expenditures.

\section{METHODOLOGY}

\subsection{The Model}

Based on Friedman's consumption theory, consumption is a function of permanent income and the interest rate. Thus, an individual's consumption depends on the income he or she is guaranteed to regularly receive at a specified time. That way, an individual can make plans based on the money they know they are going to receive. The interest rate influences consumption decisions, as individuals who want returns are willing to sacrifice some of their present consumption and increase their savings to enjoy returns in the form of interest on savings. The model of the study is a consumption model where the consumption expenditure of a household depends on income and the interest rate, amongst other variables (X). Real GDP is used to capture permanent income. The model is presented as:

$$
\mathrm{HCEPC}=\mathrm{f}(\mathrm{PI}, \mathrm{INTR}, \mathrm{X})
$$


We extend the model to capture the effect of fertility by including the total fertility rate. Testing the Kuznets curve hypothesis, which states that there is an inverted U-shaped relationship between income and inequality, we attempt to confirm if such relationship also holds between fertility and welfare. We thus examine the effect of the square of total fertility rate as an explanatory variable. Some control variables included in the study are the inflation rate, real effective exchange rate, and gross fixed capital formation. Data for the study was obtained from the World Bank (2021) World Development Indicators. The inflation rate is expected to have a negative effect on household consumption since a rise in price reduces the purchasing power of consumers and thus their expenditure. The exchange rate is expected to have a positive effect on the consumption of domestic goods, which become relatively cheaper than imported goods when the exchange rate depreciates or increases. The gross fixed capital formation represents total investment, which is expected to have an increasing effect since more household labor services would be required with increasing investment. This increases employment and household incomes.

The model therefore becomes:

$$
\text { HCEPC }=\mathrm{f}(\text { RGDP, INTR, TFR, TFRSQUARED, INF, REER, GFC) }
$$

Where

HCEPC $=$ household consumption expenditure per capita.

RGDP = real GDP.

INTR $=$ interest rate.

$\mathrm{TFR}=$ total fertility rate.

TFRSQUARED = square of total fertility rate.

$\mathrm{INF}=$ inflation rate.

REER $=$ real effective exchange rate

GFC = gross fixed capital formation.

Equation 2 is the regression model.

The functional form of the model after a logarithmic transformation is presented in Equation 3 as:

$$
\begin{aligned}
\mathrm{HCEPC}=\beta_{0}+\beta_{1} \log (\mathrm{RGDP})+ & \beta_{2} \log (\mathrm{INTR})+\beta_{3} \log (\mathrm{TFR})+\beta_{4} \log (\mathrm{TFRSQUARED})+\beta_{5} \log (\mathrm{INF})+ \\
& \beta_{6} \log (\mathrm{REER})+\beta_{7} \log (\mathrm{GFC})+\mathrm{e}_{3}
\end{aligned}
$$

The study checks for the sensitivity of the measure used by employing two welfare measures.

Thus, the real GDP per capita was also used as a measure for welfare, hence we have Equation 4.

$$
\text { RGDPPC }=\mathrm{f}(\text { INTR, TFR, TFRSQUARED, INF, REER, GFC) }
$$

Based on the Phillips-Perron unit root test and the bounds cointegration test, the autoregressive distributed lag model (ARDL) was employed. The model is given as:

$\mathrm{HCEPC}_{\mathrm{t}}=\beta_{\mathrm{o}}+\beta_{1} \log \left(\mathrm{HCEPC}_{\mathrm{t}-1}\right)+\beta_{2} \log \left(\mathrm{INTR}_{\mathrm{t}}\right)+\beta_{3} \sum_{\mathrm{p}=1}^{3} \log \left(\mathrm{INTR}_{\mathrm{t}-\mathrm{p}}\right)+\beta_{4} \log \left(\mathrm{TFR}_{\mathrm{t}}\right)+\beta_{5} \sum_{\mathrm{p}=1}^{3} \log \left(\mathrm{TFR}_{\mathrm{t}-\mathrm{p}}\right)+$ $\beta_{4} \log \left(\right.$ TFRSQUARED $\left._{\mathrm{t}}\right)+\beta_{5} \Sigma_{\mathrm{p}=1}^{3} \log \left(\right.$ TFRSQUARED $\left._{\mathrm{t}-\mathrm{p}}\right)+\beta_{4} \log \left(\mathrm{RGDP}_{\mathrm{t}}\right)+\beta_{5} \Sigma_{\mathrm{p}=1}^{3} \log \left(\mathrm{RGDP}_{\mathrm{t}-\mathrm{p}}\right)+\beta_{6} \log \left(\mathrm{INF}_{\mathrm{t}}\right)$ $+\beta_{7} \sum_{\mathrm{p}=1}^{3} \log \left(\mathrm{INF}_{\mathrm{t}-\mathrm{p}}\right)+\beta_{8} \log \left(\mathrm{REER}_{\mathrm{t}}\right)+\beta_{9} \sum_{\mathrm{p}=1}^{3} \log \left(\mathrm{REER}_{\mathrm{t}-\mathrm{p}}\right)+\beta_{10} \log \left(\mathrm{GFC}_{\mathrm{t}}\right)+\beta_{11} \sum_{\mathrm{p}=1}^{3} \log \left(\mathrm{GFC}_{\mathrm{t}-\mathrm{p}}\right)+\mathrm{e}_{3}$ (5)

The potential endogeneity of the fertility variable was controlled for with the addition of more explanatory or control variables and the presence of lagged variables in the time series.

\section{RESULTS}

The definition of the variables and the descriptive statistics are presented in Table 1.

Two measures of welfare - household consumption expenditure per capita and real GDP per capita - were used. The unit root test was conducted using the Phillips-Perron test. Some of the variables were transformed into their logarithm forms. The results showed that some variables were integrated of order zero, while some others were integrated of order one, as shown in Table 2. The bounds cointegration test was conducted for both the household consumption expenditure per capita model and the real GDP per capita model. The result for the 
household consumption expenditure per capita model revealed the presence of cointegration among the variables since the F-statistic value of 8.795 was greater than the upper bound critical value of 4.26 and significant at $1 \%$. Therefore, a short-run and a long-run model were estimated. In the case of the real GDP per capita model, the Fstatistic value of 3.337 was greater than the lower bound critical value (3.15) but less than the upper bound critical value (4.43) at the $1 \%$ significance level. Therefore, the result was inconclusive. We thus estimated both a short-run and a long-run model. The autoregressive distributed lag (ARDL) model was employed. The ARDL cointegrating and long-run form results are presented in Tables 3 and 4.

Table 1. Variable definitions and descriptive statistics.

\begin{tabular}{|c|c|c|c|c|c|}
\hline Variable & Definition & Mean & Std. Dev. & Minimum & Maximum \\
\hline $\begin{array}{l}\text { Household } \\
\text { consumption } \\
\text { expenditure per } \\
\text { capita growth }\end{array}$ & $\begin{array}{l}\text { Annual percentage growth of household } \\
\text { final consumption expenditure per capita, } \\
\text { which is calculated using household final } \\
\text { consumption expenditure in constant } 2010 \\
\text { prices and World Bank population } \\
\text { estimates (World Bank, 2021). }\end{array}$ & 1.694 & 15.194 & -24.821 & 55.434 \\
\hline $\begin{array}{l}\text { Real GDP per } \\
\text { capita }\end{array}$ & $\begin{array}{l}\text { GDP per capita is the gross domestic } \\
\text { product divided by the midyear population } \\
\text { (World Bank, 2021). }\end{array}$ & 266866.4 & 67858.64 & 199039.2 & 385349.0 \\
\hline Total fertility rate & $\begin{array}{l}\text { Total fertility rate represents the number } \\
\text { of children that would be born to a woman } \\
\text { if she were to live to the end of her } \\
\text { childbearing years and bear children in } \\
\text { accordance with age-specific fertility rates } \\
\text { of the specified year (World Bank, 2021). }\end{array}$ & 6.112 & 0.406 & 5.300 & 6.767 \\
\hline $\begin{array}{l}\text { Square of total } \\
\text { fertility rate }\end{array}$ & $\begin{array}{l}\text { The squared value of the total fertility } \\
\text { rate. }\end{array}$ & 37.518 & 4.944 & 28.090 & 45.792 \\
\hline Real GDP & $\begin{array}{l}\text { Real GDP is the sum of gross value added } \\
\text { by all resident producers in the economy } \\
\text { plus any product taxes and minus any } \\
\text { subsidies not included in the value of the } \\
\text { products (constant LCU) (World Bank, } \\
\text { 2021). }\end{array}$ & 3.68 & 1.95 & 1.62 & 7.21 \\
\hline Real interest rate & $\begin{array}{l}\text { Real interest rate is the lending interest } \\
\text { rate adjusted for inflation, as measured by } \\
\text { the GDP deflator (World Bank, 2021). }\end{array}$ & 2.049 & 9.884 & -31.453 & 18.180 \\
\hline $\begin{array}{l}\text { Real effective } \\
\text { exchange rate }\end{array}$ & $\begin{array}{l}\text { Real effective exchange rate is the nominal } \\
\text { effective exchange rate (a measure of the } \\
\text { value of a currency against a weighted } \\
\text { average of several foreign currencies) } \\
\text { divided by a price deflator or index of } \\
\text { costs }(2010=100) \text { (World Bank, 2021). }\end{array}$ & 144.183 & 116.713 & 49.733 & 536.768 \\
\hline Inflation rate & $\begin{array}{l}\text { Inflation as measured by the consumer } \\
\text { price index reflects the annual percentage } \\
\text { change in the cost to the average } \\
\text { consumer of acquiring a basket of goods } \\
\text { and services that may be fixed or changed } \\
\text { at specified intervals, e.g., yearly (World } \\
\text { Bank, 2021). }\end{array}$ & 19.103 & 17.290 & 5.388 & 72.836 \\
\hline $\begin{array}{l}\text { Gross fixed capital } \\
\text { formation }\end{array}$ & $\begin{array}{l}\text { Gross fixed capital formation consists of } \\
\text { outlays on additions to the fixed assets of } \\
\text { the economy plus net changes in the level } \\
\text { of inventories. Fixed assets include land } \\
\text { improvements (fences, ditches, drains, } \\
\text { etc.); plant machinery, and equipment } \\
\text { purchases; and the construction of roads, } \\
\text { railways, and the like, including schools, } \\
\text { offices, hospitals, private residential } \\
\text { dwellings, and commercial and industrial } \\
\text { buildings. (World Bank, } 2021 \text { ). }\end{array}$ & 34.991 & 17.173 & 14.904 & 85.934 \\
\hline
\end{tabular}

Source: Descriptive statistics were computed using data from the World Bank (2021). 
Table 2. Phillips-Perron unit root test.

\begin{tabular}{c|c|c}
\multicolumn{4}{c}{ Table 2. Phillips-Perron unit root test. } \\
\hline Variable & F-statistic (Probability) & Order of Integration \\
\hline HCEPCG & $-7.174(0.0000)$ & $\mathrm{I}(0)$ \\
\hline LOG(RGDPPC) & $-4.635(0.0007)$ & $\mathrm{I}(1)$ \\
\hline LOG(RGDP) & $-3.226(0.0265)$ & $\mathrm{I}(1)$ \\
\hline TFR & $-7.251(0.0000)$ & $\mathrm{I}(0)$ \\
\hline TFRSQUARED & $-7.595(0.0000)$ & $\mathrm{I}(0)$ \\
\hline LOG(REER) & $-4.048(0.0033)$ & $\mathrm{I}(1)$ \\
\hline LOG(GFC) & $-3.8527(0.0055)$ & $\mathrm{I}(1)$ \\
\hline INF & $-10.937(0.0000)$ & $\mathrm{I}(0)$
\end{tabular}

\subsection{The Welfare Model Using Household Consumption Per Capita}

\subsubsection{The Short-Run Model}

Model 1 is the short-run model of household consumption per capita, as presented in Table 3. The first lag of household consumption per capita had a positive, significant effect on current household consumption per capita. Thus, if there were recorded increases in the immediate previous year, there would also be improvements in household consumption per capita for the current year and vice versa. It is therefore important to maintain improvements in the growth of current year household consumption per capita in order to ensure sustained improvement in the immediate future. However, the second lag of household consumption per capita was not significant.

The current total fertility rate was not significant. Testing the Kuznets curve hypothesis, which states that there is an inverted U-shaped relationship between income and inequality, we attempt to confirm if such a relationship also holds between fertility and welfare. We thus examine the effect of the square of total fertility rate as an explanatory variable. The square of the current total fertility rate was also not significant as well as its first lag. The second lag of the square of total fertility rate was negatively significant at $5 \%$. Thus, an increase in the previous year's fertility rate significantly determines the current year household consumption per capita. Thus, while current additional childbirths may not have an immediate effect on household welfare in the short run, a depressing effect on household welfare can be linked to additional childbirths experienced in previous years. This could be as a result of the significant expenditures on food and education that become pertinent as children grow beyond the breastfeeding stage. We can see that an inverted U-shaped relationship is not established when household consumption per capita is used as a welfare measure.

The log of current real effective exchange rate was not significant, however, its first lag had a positive effect on the growth of household consumption. This implies that a percentage increase in the immediate previous year's real effective exchange rate caused a $3.2 \%$ increase in the growth of household consumption expenditure. A depreciation of the exchange rate encourages the consumption of domestic goods and hence their production. This is because imported goods become very expensive and, consequently, less desirable. Thus, the previous year's changes have implications on current household welfare. The $\log$ of current gross fixed capital formation had a negative significant effect; however, its first lag was positively significant. Thus, while a percentage increase in the current year's total investment level caused a decline in the current year's household consumption expenditure per capita growth, the current year's household welfare improvements were due to the previous year's increases in investment. Thus, any positive effect of increasing current total investment levels on welfare begins to be seen in the immediate future. Also, in this model, the real interest rate was insignificant.

\subsubsection{The Long-Run Model}

Model 2 is the long-run model of household consumption per capita and is presented in Table 4. Total fertility rate was insignificant in the long run. The inflation rate and the log of real effective exchange rate were highly negatively significant. Thus, increases in the price of domestic goods as well as foreign or imported goods have 
long-run effects on current household welfare. This is because they immediately have an impact on the quantity of goods and services that households can consume. The more expensive goods become, the less households can consume, and this depresses the utility and welfare levels of households. The log of gross fixed capital formation, the real interest rate, and real GDP were insignificant.

The post-estimation tests conducted revealed the absence of heteroskedasticity, but the presence of serial correlation, as shown in Table 5. Additionally, the presence of linearity and normality was also found.

\subsection{The Welfare Model Using Real GDP Per Capita \\ 4.2.1. The Short-Run Model}

Model 3 is the short-run model of real GDP per capita, as presented in Table 3. Current year total fertility rate was found to have a positive significant effect on the real GDP per capita in the current year. Thus, an additional childbirth caused an increase in the real GDP per capita thereby improving welfare. This could be as a result of the additional resources (whether cash or kind) that couples or families receive as gifts, and support from family and friends when there is a celebration of a new child that is born into a family. This positive, significant effect was also found for the case of the first lag of the total fertility rate.

Testing the Kuznets curve hypothesis, to confirm if it is applicable to the relationship between fertility and welfare, we examine the effect of the square of total fertility rate. The square of the current total fertility rate had a negative, significant effect on welfare, which implies that there is a turning point at which welfare begins to decline as any additional childbirth takes place. The inverted U-shaped relationship therefore holds in the relationship between fertility and welfare in the short run.

The log of gross fixed capital formation had a negative, significant effect on the current real GDP per capita. The result showed a huge magnitude of decline in the real GDP per capita as a result of a $1 \%$ increase in total investment. This could be as a result of the fact that such investments do not directly involve households so that they can earn income. This happens when more public investments are financial investments instead of direct investments. Finally, the real effective exchange rate and the real interest rate were not significant.

Table 3. The Short-Run Welfare Model Using Household Consumption Per Capita (Model 1) and Real GDP Per Capita (Model 3).

\begin{tabular}{|c|c|c|c|}
\hline $\begin{array}{l}\text { Variables in Model } 1 \\
\text { Dependent variable is household } \\
\text { consumption per capita growth }\end{array}$ & $\begin{array}{c}\text { Model } 1 \\
\text { Coefficient }(\mathrm{t}- \\
\text { statistic) }\end{array}$ & $\begin{array}{l}\text { Variables in Model } 3 \\
\text { Dependent variable is } \\
\text { real GDP per capita }\end{array}$ & $\begin{array}{c}\text { Model } 3 \\
\text { Coefficient(t- } \\
\text { statistic) }\end{array}$ \\
\hline $\mathrm{D}(\mathrm{HCEPCG}(-1))$ & $0.798(3.315)^{*}$ & $\mathrm{D}(\mathrm{TFR})$ & $15335774.734(0.000)^{*}$ \\
\hline $\mathrm{D}(\mathrm{HCEPCG}(-2))$ & $0.256(2.047)$ & $\mathrm{D}(\mathrm{TFR}(-1))$ & $2149845.477(4.573)^{*}$ \\
\hline $\mathrm{D}(\mathrm{TFR})$ & $-31927.618(-2.166)$ & $\mathrm{D}(\mathrm{INF})$ & $-108.808(-0.848)$ \\
\hline D(TFRSQUARED) & $2914.269(2.193)$ & DLOG(REER) & $4580.387(1.178)$ \\
\hline D(TFRSQUARED $(-1))$ & $539.474(1.953)$ & $\operatorname{DLOG}(\operatorname{REER}(-1))$ & $132.310(0.029)$ \\
\hline D(TFRSQUARED $(-2))$ & $-407.900(-2.445)^{* * *}$ & $\operatorname{DLOG}(\operatorname{REER}(-2))$ & $7085.478(1.913)$ \\
\hline $\mathrm{D}(\mathrm{INF})$ & $-0.394(-1.618)$ & $\mathrm{D}(\mathrm{RIR})$ & $171.928(1.009)$ \\
\hline $\mathrm{D}(\mathrm{INF}(-1))$ & $0.500(2.245)$ & $\mathrm{DLOG}(\mathrm{GFC})$ & $-23139.930(-2.167)^{* * *}$ \\
\hline DLOG(REER) & $5.528(0.653)$ & D(TFRSQUARED) & $\begin{array}{c}-1437207.874(- \\
3.462)^{*}\end{array}$ \\
\hline DLOG(REER(-1)) & $31.756(4.856)^{*}$ & CointEq(-1) & $-0.441(-4.306)^{*}$ \\
\hline DLOG(REER(-2)) & $13.540(1.454)$ & & \\
\hline DLOG(RGDP) & $74.712(0.816)$ & & \\
\hline DLOG(RGDP $(-1))$ & $223.501(2.612)^{* * *}$ & & \\
\hline $\mathrm{D}(\mathrm{RIR})$ & $0.326(1.073)$ & & \\
\hline $\mathrm{D}(\operatorname{RIR}(1))$ & $-0.435(-1.615)$ & & \\
\hline $\mathrm{DLOG}(\mathrm{GFC})$ & $-102.757(-5.079)^{*}$ & & \\
\hline $\mathrm{DLOG}(\mathrm{GFC}(-1))$ & $127.542(3.847)^{*}$ & & \\
\hline CointEq $(-1)$ & $-2.503(-7.118)^{*}$ & & \\
\hline
\end{tabular}




\subsubsection{The Long-Run Model}

Model 4 is the long-run model of real GDP per capita and is shown in Table 4. Here we find that a U-shaped relationship holds in the long run. An increase in the total fertility rate causes the log of current real GDP per capita to decline by a huge magnitude. However, over time, there is a turning point when additional childbirths begin to cause an increase in the current year's real GDP per capita, as shown by the positive, significant effect of the square of the total fertility rate.

Therefore, while an inverted U-shaped relationship was obtained in the short run, in the long run it reverts to a $\mathrm{U}$ shape. The positive effect after the turning point shows the possible demographic dividend where the dependent population grows to become the working population, thereby contributing to output growth.

The post-estimation tests conducted revealed the absence of heteroskedasticity and serial correlation, as shown in Table 6. The presence of linearity and normality was also found.

Table 4. The Long-Run Welfare Model Using Household Consumption Per Capita (Model 2) and Real GDP Per Capita (Model 4).

\begin{tabular}{l|c|c|c}
\hline $\begin{array}{l}\text { Variables in Model 2 } \\
\text { Dependent variable is household } \\
\text { consumption per capita growth }\end{array}$ & $\begin{array}{c}\text { Model 2 } \\
\text { coefficient(t- } \\
\text { statistic) }\end{array}$ & $\begin{array}{c}\text { Variables in Model 4 } \\
\text { Dependent variable is } \\
\text { real GDP per capita }\end{array}$ & $\begin{array}{c}\text { Model 4 } \\
\text { Coefficient(t-statistic) }\end{array}$ \\
\hline TFR & $99.248(0.244)$ & TFR & $-3679540.352(-4.775)^{*}$ \\
\hline INF & $-0.682(-3.993)^{*}$ & INF & $-246.652(-0.856)$ \\
\hline LOG(REER) & $-18.572(-5.365)^{*}$ & LOG(REER) & $13873.517(-1.340)$ \\
\hline LOG(RGDP) & $-31.512(-1.310)$ & RIR & $389.736(0.958)$ \\
\hline RIR & $-0.014(-0.068)$ & LOG(GFC) & $-52454.716(-2.513)^{* *}$ \\
\hline LOG(GFC) & $-91.289(-4.731)$ & TFRSQUARED & $267679.697(4.624)^{*}$ \\
\hline TFRSQUARED & $7.893(0.290)$ & CONSTANT & $12983143.968(5.131)^{*}$ \\
\hline CONSTANT & $491.549(0.230)$ & & \\
\hline
\end{tabular}

Note: * significant at the $1 \%$ level.

*** significant at the $5 \%$ level.

Table 5. Diagnostic Checks for the Household Consumption Per Capita Model.

\begin{tabular}{l|c|c}
\hline Test & F Statistic & Probability \\
\hline Heteroskedasticity test: ARCH & 0.631 & 0.4329 \\
\hline Breusch-Godfrey serial correlation LM test & 5.364 & 0.0387 \\
\hline Ramsey RESET test for linearity & 1.081 & 0.3289 \\
\hline Jarque -Bera test for normality & 5.694 & 0.0580 \\
\hline
\end{tabular}

Table 6. Diagnostic Checks for the Real GDP Per Capita Model.

\begin{tabular}{l|c|c}
\hline Test & F Statistic & Probability \\
\hline Heteroskedasticity test: ARCH & 0.353 & 0.5563 \\
\hline Breusch-Godfrey serial correlation LM test & 3.310 & 0.0584 \\
\hline Ramsey RESET test for linearity & 0.523 & 0.4778 \\
\hline Jarque-Bera test for normality & 0.7816 & 0.6765 \\
\hline
\end{tabular}

\section{DISCUSSION}

The negative or depressing effect of fertility on household consumption expenditure in the short run is similar to what was found by Desta (2014), Makarski et al. (2019) and Masanja et al. (2016). As fertility levels increase, the population grows and the available resources become inadequate, such that average resources decline. This causes welfare levels to worsen. It is also pertinent that if policies do not control the rise in fertility, then they must be directed towards making deliberate plans for the future to engage the consequential number of young working people in order to prevent welfare decline.

The inverted $U$ shape shown in the fertility effect on income per capita indicates that there is a threshold beyond which growth in fertility levels become burdensome. Thus, intentional fertility control policies are inevitable. On the other hand, the long-run possibility of a demographic dividend, indicated by the U-shaped relationship, make it important to have deliberate strategies for making the dividend a reality. 
The negative effect of the gross fixed capital formation emphasizes the fact that, in the long run, it is also important to improve the inclusiveness of investment efforts to directly improve individual and household welfare.

\section{CONCLUSION}

The total fertility rate has a negative, significant effect on household consumption expenditure in the short run. This is also confirmed when the real GDP per capita is used as a welfare measure and an inverted U-shaped relationship is seen in the short run implying that, ultimately, welfare levels decline. There is the possibility of a demographic dividend in the long run where a U-shaped relationship holds. Fertility policies must therefore endeavor to control for the immediate or short-run negative effect of rising fertility rates and make deliberate plans to engage the future large working population in order to reap the possible demographic dividend.

Funding: This study received fifty percent financial support for publication fee from Babcock University.

Competing Interests: The author declares that there are no conflicts of interests regarding the publication of this paper.

\section{REFERENCES}

Adebiyi, O. O., \& Olomola, A. P. (2016). Female employment and fertility decisions; is there an implication for household consumption in south-west Nigeria? Humanities and Social Sciences Letters, 4(3), 62-68. Available at: https://doi.org/10.18488/journal.73/2016.4.3/73.3.62.68.

Becker, G. S. (1960). An economic analysis of fertility, 209-240, In Demographic and Economic Change in Developed Countries, Columbia University Press. National Bureau of Economic Research. Retrieved from: http://www.nber.org/chapters/c2387.

Becker, G. S. (1965). A theory of the allocation of time. The Economic Journal, 75(299), 493-517.

Brewer, M., \& Ratcliffe, A. (2012). Does welfare reform affect fertility? Evidence from the UK. Journal of Population Economics, 25(1), 245-266. Available at: https://doi.org/10.1007/s00148-010-0332-x.

Caldwell, J. C. (1977). The economic rationality of high fertility: An investigation illustrated with Nigerian survey data. Population Studies, 31(1), 5-27. Available at: https://doi.org/10.2307/2173485.

Desta, C. G. (2014). Fertility and household consumption expenditure in Ethiopia: A study in the Amhara Region. Journal of Population and Social Studies, 22(2), 202-218.

Huang, J.-T., Pan, J.-N., Chang, M.-L., \& You, S.-Y. (2019). Low fertility rate and consumption behavior of households in Taiwan. The Singapore Economic Review, 64(1), 175-190. Available at: https://doi.org/10.1142/S021759081750014X.

Kanayo, O., Chinelo, O., \& Sathiya Susuman, A. (2016). Consumption and population dynamics in Nigeria: Analysis and micro simulations using fertility rate variants. Journal of Asian and African studies, 51(6), 700-717. Available at: https://doi.org/10.1177/002 1909614557294.

Kim, J., Engelhardt, H., Prskawetz, A., \& Aassve, A. (2005). Does fertility decrease the welfare of households? An analysis of poverty dynamics and fertility in Indonesia. Vienna Institute of Demography Working Papers, No. 06/2005, Austrian Academy of Sciences (ÖAW), Vienna Institute of Demography (VID), Vienna.

Libois, F., \& Somville, V. (2018). Fertility, household size and poverty in Nepal. World Development, 103, 311-322. Available at: https://doi.org/10.1016/j.worlddev.2017.11.005.

Makarski, K., Tyrowicz, J., \& Malec, M. (2019). Fiscal and welfare effects of raised fertility in Poland: Overlapping generations model estimates. Population and Development Review, 45(4), 795-818. Available at: https://doi.org/10.1111/padr.12297.

Masanja, G. F., Lwankomezi, E., \& Emmanuel, C. (2016). The effects of declining fertility on household socioeconomic conditions in Tanzania: A comparative study of urban versus rural areas of Kwimba District, Mwanza region. International Journal of Population Research, 1-14. Available at: https://doi.org/10.1155/2016/4716432. 
Moffitt, R. A. (1998). The effect of welfare on marriage and fertility: What do we know and what do we need to know? In Welfare, the family, and reproductive behavior: Research Perspectives, edited by R.A. Moffitt (pp. 59-97). Washington, DC: National Academy Press.

Obiyan, M. O., Fagbamigbe, A. F., Adetutu, O. M., \& Oyinlola, F. F. (2017). Fertility, labour force participation and poverty among married women in Nigeria. African Population Study, 31(1S2), 3408-3420. Available at: https://doi.org/10.11564/31-1-999.

Odusola, A. (2018). Poverty and fertility dynamics in Nigeria: A micro evidence. Retrieved from https://ssrn.com/abstract=3101818. [Accessed January 14, 2018]

Owoo, N. S. (2021). Demographic considerations and food security in Nigeria. Journal of Social and Economic Development, 23(1), 128-167. Available at: https://doi.org/10.1007/s40847-020-00116-y.

Schultz, T. P. (2005). Fertility and income. Center Discussion Paper, No. 925, Yale University, Economic Growth Center, New Haven, CT

World Bank. (2021). World development indicators database. World Bank Group. Retrieved from: https://databank.worldbank.org.

Wusu, O., \& Amoo, E. O. (2016). Fertility behaviour and wealth situation in Nigeria: Evidence from 2013 demographic and health survey. Social Indicators Research, 128(1), 1-14. Available at: https://doi.org/10.1007/s11205-015-1016-4.

Yusuf, S. A. (2008). Social capital and household welfare in Kwara State, Nigeria. Journal of Human Ecology, 23(3), $219-229$. Available at: https://doi.org/10.1080/09709274.2008.11906074. 